\title{
Intermédialités
}

Histoire et théorie des arts, des lettres et des techniques

Intermediality

History and Theory of the Arts, Literature and Technologies

\section{Dwelling in Mobility}

\section{Maria-Thalia Carras}

Numéro 10, automne 2007

Disparaître

Disappearing

URI : https://id.erudit.org/iderudit/1005560ar

DOI : https://doi.org/10.7202/1005560ar

Aller au sommaire du numéro

Éditeur(s)

Centre de recherche sur l'intermédialité

ISSN

1705-8546 (imprimé)

1920-3136 (numérique)

Découvrir la revue

Citer cet article

Carras, M.-T. (2007). Dwelling in Mobility. Intermédialités / Intermediality, (10),

183-187. https://doi.org/10.7202/1005560ar d'utilisation que vous pouvez consulter en ligne.

https://apropos.erudit.org/fr/usagers/politique-dutilisation/ 


\title{
Dwelling in Mobility
}

\author{
Maria-Thalia Carras
}

t's June 2003, it's hot, and Athens is preparing for the 2004 Olympics-there is little more than one year to go. All eyes are on Athens, a booming city; corporate buildings rise over large boulevards, marble gleams, stadiums overpower. Maria Papadimitriou invites us to another part of town-it too is expanding, roads though here lead to nowhere, apart from what could best be described as a shanty town. DIY buildings in glorified impermanence surround a neat square. A former world champion wrestler and his kick ass girlfriend host a bar on the corner of the square. Nobody speaks Greek here, only Russian. Maria Papadimitriou has placed her Luv Car (TransBonanza Platform for Public Events), in the centre of the square. Towards evening, when some respite from the heat comes, a strange camaraderie of unusual suspects made of art world hangers on, Gypsies and Vlach Romanians, a few Russians from Pontos, and other such like, sing karaoke to disco anthems and dance like crazy, together, in the square. Night comes and the wind becomes a bit chilly. Papadimitriou closes shop, the van drives off, and we all go home. Some people stay on drinking at the ex-wrestler's bar. Papadimitriou's project silently disappears; quickly and efficiently like a trickster's work of magic. Again and again Papadimitriou's projects vanish into thin air, one minute they're there, the next they're gone, transforming into memories of shared experiences.

It is the experiential nature of Maria Papadimitriou's work-open and generous, steeped in human generosity, time based and on the margins of what is normalized in society-that reflects her ideas about appearances and disappearances mostly. This is mainly because her work is un-iconic, based more on feelings that later transform into images, rather than images which generate feelings. Indeed if there is one artist who has been an influence on her work it is the Brazilian artist Helio Oiticica who, working in the 196os, managed to linger on the periphery, in the favelas, configuring a romantically glamorous approach to art production and collaborating with the marginalized while his poetic social sculptures and "parangole" aimed to alter people's reality even if only momentarily. 
Papadimitriou's projects are also social sculptures. Both because they raise questions about society and those excluded from it but also because they need people and society to exist. Her work is not based on commonplace interactions -instead, the very fabric of society becomes interlaced with Papadimitriou's projects, in which in turn they create small but crucial shifts. She creates parallel structures which are inclusive to everyone and anyone. Her seemingly utopian intersections seem close in spirit to the Situationists architectural and urban ideals, except that in Papadimitriou's case they are steeped in the sweat and toil of humanity. Papadimitriou's projects connect an architectural and social utopianism with reality, merging them into a sort of utopian realism. Her inability as an artist to actually recreate societal systems allows her the artistic freedom to create "illegal" para-systems that last but a few moments, hours, days-as long as the given exhibition lasts. These momentary shifts usually inhabit different time zones, alternative realities, rising spontaneously in stark contrast to the computed fast paced erosion of anything that stands out from the norm in late capitalist culture.

This is the case with TAMA (Temporary Autonomous Museum for All) located in the outskirts of Athens, in Avliza, one of Papadimitriou's longest standing collaborative projects. Her involvement with TAMA started in 1998 when she stumbled across it by accident and as she herself describes it,

What I saw there is the concept of a makeshift settlement, a kind of mobile post-urban city which serves its inhabitants' temporary housing needs and economic activities. Everything forms part of this town. Landscape-clothes-interiors-unfinished buildings-streets - cars - the sky - the people. I started to visit Avliza every day-I became an addicted visitor... The nomadic way of living and the particularities of the community gave me the idea of setting up a system of communication and exchange among the inhabitants, myself, the art people and the public. ${ }^{1}$

TAMA, as the title and Papadimitriou herself hints, is both socially allinclusive as well as ephemeral to the core. TAMA, however, is not only allinclusive notionally but also in practice, due to the very materials that Maria Papadimitriou uses. As Jennifer Allen argues,

her building materials-cheap, found, second-hand-are ready-mades that resist being hauled away, whether by thieves, vandals or municipal garbage collectors. With this choice of materials, Papadimitriou explores the strange category of rubbish: things that exist in a state of suspension because they are not quite being used, but they have not yet been thrown away. ${ }^{2}$

1. Maria Papadimitriou, "TAMA," Maria Papadimitriou (ed.), T.A.M.A. (25th Bienal de Sao Paolo), Athens, Futura, 2002, p. 13.

2. Jennifer Allen, "Maria Papdimitriou," Babi Scardi (ed.), Less: Alternative Living Strategies, Five Continents Editions, Milano, 2006, p. 207. 
Two abandoned one-armed chairs prove the best of company, whilst cardboard doors half-fitted into a makeshift construction seem singularly free compared to the closedeness of the coloured bird cage hanging off them. Maria Papadimitriou's projects hover like these leftover goods: ambivalently in a state of suspension, tantalizing the viewer as they drift between existing and not-existing, formation and deconstruction, appearing and disappearing.

TAMA was created in a distinctly ambivalent space, a blind spot among disparate communities, between the urban and the sub-urban. As a collaboration with the Vlach Romanian community as well as with the artistic and architectural community of Athens, TAMA is still constantly being formed and de-formed. It provides the structural basis for an interconnective rhizome of ideas and people who often live out of the norm, unrepresented or misrepresented. The uniconic element is again strongly felt: networking processes based on human relationships rather than images per se are indeed crucial in Maria Papadimitriou's work. Image practically disappears to make way for a more complex set of interrelationships, between communities as well as between individual people.

What is at stake here is the openness and accessibility of public space. Papadimitriou's project transforms architecture and public spaces into an open ended dialogue, a place for people to really meet, a forum for dialogue and ideas, a utopian democracy of forms. Yorghos Tzirtzilakis joins in the debate over these spontaneous Roma settlements and the interest they provoke in terms of city development:

Of course, these people are associated with an almost primitive model of life and dwelling, always temporary and under a state of persecution. Yet this same state promotes the "otherness" and the mythologies of a population still accompanied by secrets and spirits. [...] Maria Papadimitriou processes these contradictory elements through discussions with her friends and associates. In Avlida the power of the metropolitan tornado most people today call "nomadism" defies all those who describe it as the dominant model of the future and asserts itself as a "vulgar" local peculiarity. [...] Above all, however, this transient town subverts all prefabricated images. ${ }^{3}$

As Tzirtzilakis text suggests, the marginalized populations that Papadimitriou collaborates with, along with the subtext of her relationship to them, constitute a distinctive critique of ungenerous capitalist practices.

3. Yorghos Tzirtzilakis, "Reality as a Strategy, Observation as Destiny", in Maria Papadimitriou (ed.), T.A.M.A. (25th Bienal de Sao Paolo), Athens, Futura, 2002, p. 26. See also Yorghos Tzirtzilakis, «Social Topography and Collaborative Promiscuity: the Temporary Autonomous Museum for All in Athens », o Monografias, 3 (Casa House), Colexio oficial de Arquitectos de Galicia, Primavera 2005, p. 194-197. 
TAMA negotiates a resurfacing of the otherwise unknown and invisible lives of the inhabitants of Avliza's shanty towns out of the depths of our social unconsciousness. Its pertinence resides in the fact that it is an investigation of an invisible city - a city on the outskirts, a city for which there is no room in our public imaginary apart from the one created by rare works such as Konstantinos Yannaris' film From the Edge of the City (2001) which presents the lives of marginalized young immigrants from Kazakhstan. The Vlach Romanians live on the edge of our city and consciousness.

Maria Papadimitriou's projects, both ephemeral and community-based, often entertain a paradox: they constantly disappear whilst making issues and social problems that society would happily ignore persistently reappear. In Hotel Plug-Inn, one of Papadimitriou's most recent works, at the Canary Islands Biennial, the materials of her project were literally the residues of a disappearance, potentially even of that final disappearance, death. In an ironic play with history, Papadimitriou transformed the Spanish San Gabriel castle, imposingly overlooking the Atlantic Ocean, into a figural welcoming zone for illegal immigrants, emotionally and physically exhausted from their voyage. Similar to theatrical plays where all the action happens off scene, in Hotel Plug-Inn, a whole story is narrated while the main characters are nowhere to be seen. Papadimitriou used the wooden boats that carry migrants jam-packed from Africa hoping for a more prosperous future as the basis for the castle's new furniture. She remodelled them into beds for a long dreamed-of sleep, into benches of rest in a memory room where music from their homelands could be listened to, and even installed a cloak room in which they could hang exhausted clothes. The emigrants' protective outer layers, their clothes and boats, are used as hosts to a fresh wave of less anguished art travellers, offering them solace and rest in the dreary run of a large scale art exhibition.

What marks Papadimitriou's work is the emigrants' absence and silence. For all we know, the people whose plight is exposed have disappeared, only to revitalise the places and spaces that we work and live in: they are the unknowns that surround us, whose histories and pained process of travel we can only imagine. Papadimitriou points at their disappearance whilst making us conscious of the void they leave behind: outer shells of transport, their boats.

It is a quite different voyage from one state to another that Maria Papadimitriou worked on for her project in Puerto Rico, Hypotheses 2, The Soul Message Formula, Illumina tus Suenos, Amphiareion, 2002. She created a healing center inspired by the Greek oracle and healer demigod Amphiaraos. People were invited to sleep on makeshift beds in the outdoor landscape as if these beds could gain them entry into some other world. They were surrounded by a tropical paradise and welcomed to rest, sleep and thus be transported and delve into 
a space of dreams, while venturing to revive Greek mythological practices-a magical world suppressed by everyday normality. The metaphor of departure was highlighted again by the constructions that visitors were invited to lie on: ready-made constructions built out of the doors of local rundown supermarkets. Personal dreams in this public space, Papadimitriou suggests, could tap into a deeper communal subconscious, unearthing hidden depths and illuminating dark messages from the soul.

It is these interrelationships between the conscious and the subconscious, between different kinds of past histories, communal and personal, that Papadimitriou's projects bring to the fore and work on. People, places and memories, and a constant movement between all three, give to Maria Papadimitriou's projects their peculiar human vitality. The projects may be constantly in the process of disappearing but as they do, they allow for other quite complex feelings to emerge. 